Nordic Journal of Modern Language Methodology

\title{
Fremmedspråkundervisningen i Norge. Nye veger, nye dører, nye muligheter
}

\author{
av Beate Lindemann og Annelise Brox Larsen
}

\begin{abstract}
Norwegian pupils only achieve a low level of proficiency in third languages such as French, German and Spanish. With that startingpoint the article wants to explore new ways of introducing these languages in school. The project considers different models of organizing third language education in European countries such as Germany and the Netherlands, and evaluates the possibilities for adapting similar models in schools in Norway.
\end{abstract}

\section{Innledning}

Norske elever og studenter er rimelig flinke i engelsk. Etter å ha lært språket siden 1 . klasse på skolen, hørt det på radio, tv, kino og dvd, lyttet til engelskspråklige sanger, brukt språket på nett og i spill osv., er unge mennesker i dag fortrolige med språket og bruker engelsk som oftest uten store problemer. ${ }^{1}$ Verre er det med ferdighetene i og kunnskaper om andre fremmedspråk enn engelsk. Tradisjonelt finnes det en første mulighet - men ikke obligatorisk - til å lære et tredjespråk ${ }^{2}$ i 8 . klasse på ungdomsskolen. ${ }^{3}$ Ideelt sett lærer eleven deretter språket tre år på ungdomsskolen, to år på videregående skole (nivå II) og eventuelt ett år til som fordypning (nivå III). Etter hhv. fem eller seks år med språklæring burde kunnskapene og ferdighetene være ganske gode. Inntrykket er dessverre ikke helt slik når vi ser på prestasjonene i avgangsklassene. Det finnes selvsagt elever med svært gode fransk-, tysk- eller spanskkunnskaper, men gjennomsnittselevene kan knapt sies å nå A2-nivå (etter den Felleseuropeiske referanserammen for språk). Elevene som først starter i 1. klasse på videregående skole med et fremmedspråk, skal etter fagplanen nå samme språklige nivå som elevene som

1 I en undersøkelse av engelskferdighetene blant 10. klassinger eller tilsvarende i sju europeiske land utmerket de norske elevene seg ved å være flinkere enn sine europeiske kolleger i muntlige ferdigheter (Ibsen 2004). Studien til Hellekjær 2007 viser likevel at engelskkunnskapene til nordmenn ikke er nok og at det også er behov for kunnskap i flere fremmedspråk .

${ }^{2}$ Som tredjespråk betegnes alle fremmedspråk som tilegnes etter morsmålet og første fremmedspråk, som i svært mange land er engelsk.

${ }^{3}$ Vi ser her bort fra at det nå settes i gang med ulike pilotprosjekter der elevene møter tredjespråket allerede i barneskolen. Vi kommer tilbake til dette senere i artikkelen. 
startet på ungdomsskolen ${ }^{4}$, men også her er hovedinntrykket at kun et fåtall av elevene når dette målet. ${ }^{5}$

Ved universitetene og høyskolene er tredjespråkene blant de fag som trekker til seg få studenter. De som velger å studere et slikt fremmedspråk, skal ifølge målene i studieplanene nå nivået $\mathrm{B} 1 / \mathrm{B} 2$ etter lavere grads studier (to eller tre semester studier) eller $\mathrm{C} 1 / \mathrm{C} 2$ etter masterstudier ( 7 semester studier). ${ }^{6}$

Eksamener og lignende er ferdighetsevalueringer knyttet til en utdanningsinstitusjon. Utover dette er det rimelig å bedømme ferdighetene med henblikk på hvorvidt de tilsvarer de kunnskapene og språkferdighetene som fremtidige arbeidsgivere etterlyser hos sine ansatte, eventuelt også ferdighetene som kreves med tanke på studier og yrkesrettede utdanninger.

Næringslivet etterspør gode ferdigheter i fremmedspråk utenom engelsk innenfor mange bransjer. De muligens mest åpenbare er turisme og hotell- og restaurantbransjen. Men det finnes langt flere områder med store fremmedspråkbehov. Særlig tysk og fransk er viktige språk for handelen med utlandet. Tyskland er Norges viktigste handelspartner og uten tvil ett av de viktigste land i EU. Frankrike er hovedmottaker for norsk fisk. Gode språk- og ikke minst kulturkunnskaper åpner viktige dører til etablerte og nye markeder. Men kunnskapene til medarbeiderne strekker ofte ikke til. Denne kunnskapsmangelen har mange negative konsekvenser for den enkelte bedrift og for norsk økonomi mer generelt.

\begin{abstract}
"Hvis man ikke kan tysk får man et problem." (Jon Hanssen, fiskeriattaché ved Generalkonsulatet i Hamburg og representant for Eksportutvalget for fisk; sitert etter Gaarder 2003:43)

"Man må ikke tro at man kommer i dybden hvis man snakker engelsk $i$ et land hvor dette ikke er morsmålet. Vi må for eksempel kunne forstå det som skjer lokalt og forstå noe mer enn på overflaten, og vi må nok kunne forstå kulturtradisjonene dersom vi virkelig vil oppnå noe," sier Nergaard og viser til at ca. 100 millioner mennesker snakker tysk i Europa, i et område som er et økonomisk kraftsenter. "Kort og godt: hvis man vil gjøre forretninger i Tyskland, trenger man rett og slett god språk- og kulturforståelse.” Leiv L. Nergaard, direktør I Norsk Hydro; sitert etter Gaarder 2003:46)
\end{abstract}

Norsk næringsliv og høyere utdanningsinstitusjoner her hjemme konstaterer derfor med tanke på språkkunnskapene til norske elever (og studenter): " Norsk ungdom kan ikke nok, og de kan ikke det som trenges."

\footnotetext{
${ }^{4}$ Se fagplanene på http://www.udir.no/Lareplaner/Grep/Modul/?gmid=0\&gmi=4513 .

${ }^{5}$ Ferdighets- og kunnskapsnivået til elevene knyttet opp mot kompetansemålene i læreplanene er dessverre aldri blitt undersøkt. Likevel er det mulig å danne seg et (subjektivt) bilde av "nivået" gjennom samtaler med faglærere, observasjoner i klasserommene, tilbakemeldinger fra tidligere elever og fremtidige arbeidsgivere og gjennom de faglige kunnskapene som studentene starter språkstudiene med.

6 Referanserammen nevnes ikke alltid i studieplanene. Likevel vil kompetansemålene i studiene kunne sammenlignes med de målene som referanserammen setter opp.

${ }^{7}$ En siste påminnelse om dette ga en stor konferanse om tysk-kompetanse og norsk næringsliv 12.10.2011 i Oslo, der bl.a. NHO-direktøren John G. Bernander og statsråd Tora Aasland konstaterte store behov for bedre tysk-kompetanse hos norsk ungdom og folk under utdanning (se også www.nho.no/kompetanse-ogutdanning/spraak-er-loennsom-investering-article23875-56.html ).
} 


\section{2. "Større mangfold og bredde i opplæringen i fremmedspråk"}

I strategiplanen "Språk åpner dører" (rev.utg. 2007) er ett av de overordnede målene: "Bedre ferdigheter i flere fremmedspråk hos elever, lærlinger og lærere i grunnskole og videregående opplæring og økt interesse og motivasjon for språklæring" (Språk åpner dører, rev.utg. 2007, 38). Ett av hovedtiltakene for å nå dette målet er "større mangfold og bredde i opplæringen i fremmedspråk" (Språk åpner dører, rev.utg. 2007, 38).

Retter vi blikket litt utenfor Skandinavia, ser vi fort at elevene der ofte lærer mange språk og oppnår gode praktiske språkkunnskaper. Vi vil i denne sammenhengen verken evaluere andre lands fremmedspråkundervisning eller sette norsk undervisning opp mot det man gjør i utlandet. Vi ønsker derimot å sette fokus på språkundervisning i utlandet for å hente inspirasjon og gode idéer med overføringsmuligheter til norske klasserom.

Fremmedspråkdidaktikkgruppa ved Universitetet i Troms $\varnothing^{8}$ har fått midler ${ }^{9}$ for å kunne se nærmere på språkundervisningen i (hovedsakelig) Tyskland med tanke på inspirasjon til nyskapende prosjekter her hjemme. Vi har besøkt og delvis hospitert ved tyske skoler der man prøver å tilby undervisning i tredjespråk på nye måter. Vi prøver å kaste et kritisk blikk på tiltakene og ønsker å legge fram eksempler på good practice slik at aktuelle norske skoler kan bli motivert til utprøving, dvs. omsetting til praksis etter en tilpasning til egne rammevilkår. Vi støtter oss på våre egne observasjoner og aktuell forskning når vi samtidig ønsker å komme med råd om hvordan disse nyskapende modellene kan gjennomføres innenfor norske rammer. Artikkelen er i hovedsak ment som et diskusjonsbidrag på den fremmedspråkdidaktiske arenaen. Men bidraget kan også være en inspirasjonskilde for rektorer, lærere, elever og deres foreldre. "Større mangfold og bredde i opplæringen i fremmedspråk" krever til dels mye nytenkning med henblikk på organisatoriske aspekter ved opplæringen. ${ }^{10}$ Også i Norge skal vi kunne nå EU og Europarådets mål om beherskelse av minst to fremmedspråk. En ny veg mot dette målet kan være at vi supplerer dagens tradisjonelle fremmedspråkundervisning med for eksempel nye opplæringstilbud.

I denne artikkelen gis det nå først i kapittel 3 et lite overblikk over opplæringstilbud som vil kunne være interessante å se nærmere på med tanke på norske forhold. Kapittel 4 diskuterer mulighetene og begrensningene for innføringen av slike opplæringstilbud i Norge, mens det avsluttende kapittel prøver å kaste et kort blikk inn i fremtiden.

\section{Et overblikk over aktuelle opplaringstilbud innenfor tredje-/ fremmedspråk}

I dette kapittelet kommer vi til å presentere nyskapende tiltak som vi har blitt kjent med gjennom (hovedsakelig) tyske skoler og som vi opplever som lovende med tanke på en

\footnotetext{
${ }^{8}$ Gruppen ledes av førsteamanuensis Beate Lindemann og førsteamanuensis Annelise Brox Larsen, begge fra Fakultetet for Humaniora, samfunnsvitenskap og lærerutdanning, Universitetet i Tromsø.

${ }^{9}$ Prosjektet finansieres av DAAD og er et samarbeidsprosjekt mellom fremmedspråkdidaktikkgruppen ved Universitetet i Tromsø og Fachgruppe Mehrsprachigkeitsforschung und DaF/DaZ ved TU Darmstadt.

${ }^{10}$ Vi bruker her bevisst begrepet "opplæring" istedenfor "undervisning" for å påpeke at det også vil kreves en ny praktisk definisjon av tradisjonell norsk undervisning i 2 . fremmedspråk.
} 
mulig implementering i Norge. Tilbudene vil presenteres slik at fordeler og mulige ulemper eller vanskelige momenter kommer fram, men det legges ikke opp til en evaluering av disse tilbudene. ${ }^{11}$

\subsection{Tidlig start: flere fremmedspråk for videregående}

Tyskland består av 16 Bundesländer med egne utdanningssystem. Oppbyggingen av skolesystemet i de enkelte delstatene ligner på hverandre, men er ikke helt lik. Dette gjelder også for fremmedspråkopplæringen. Likevel finnes det fellestrekk. I barneskolen ("Primarbereich", 1.-4. klasse) møter elevene som oftest for første gang et fremmedspråk, vanligvis engelsk. De fleste elevene får organisert undervisning i 1. fremmedspråk (engelsk, men også fransk, italiensk og lignende) fra 3. klasse, 2. fremmedspråk fra 6. eller 7. klasse (Gymnasium ${ }^{12}$ ) og 3. fremmedspråk fra 8. eller 9. klasse (Gymnasium) (Bausch/Helbig 2003, Christ 2003). 3. fremmedspråk er for de fleste elevene ikke obligatorisk. Det finnes dessuten flere prosjekter med fremmedspråkundervisning allerede fra 1. klasse og tilbud om andre 1. fremmedspråk enn engelsk (Rück 2006).

Vi kan konstatere at elevene i Tyskland faktisk starter senere med sitt 1. fremmedspråk enn vi, men at de starter med 2. fremmedspråk allerede i 6. eller 7. klasse, dvs. i 12årsalderen. ${ }^{13}$ Observasjoner i klasserom og samtaler med elever og lærere bekrefter inntrykket av at dette er et vellykket tiltak. ${ }^{14}$ Elevene i denne aldersgruppen liker å ta språket i bruk både muntlig og skriftlig, samtidig som de er nysgjerrige på språksystemet som ligger bak. De viser en genuin interesse for å lære nye ord og å sammenligne aspekter ved morsmålet med det nye språket (og gjerne også med engelsk) (FröhlichWard 2003). Det undervises gjennomsnittlig tre timer i uka i 2. fremmedspråk. Hovedfokuset ligger på korrekt språkbruk, dvs. formidling av grammatiske regler og innlæring av ord og uttrykk. Etter 9./10. klasse ${ }^{15} \quad$ skal elevene nå nivå A2/B1 etter referanserammen. Etter ytterligere tre år på videregående skole skal nivået $\mathrm{B} 1 / \mathrm{B} 2$ nås. Om ønsket kan elevene dessuten lære et 3. fremmedspråk fra 8./9. klasse. Tilbudet tas imot av de fleste elevene på Gymnasium. Et 3. eller til og med 4. fremmedspråk kan også læres på den videregående skolen (Gymnasiale Oberstufe).

11 Det finnes per i dag ingen vitenskapelige evalueringer av de beskrevne opplæringstilbudene. Vi kan derfor ikke vise til "vitenskapelige data", men støtter oss til de tilbakemeldingene vi har fått fra brukerne selv - rektorene, faglærerne og elevene.

12 Det tyske utdanningssystemet kan i grunntrekkene skisseres slik:

1.-4. klasse barneskole (Grundschule), 5.-9.(10.) klasse tredelt tilbud: Gymnasium, Realschule og Hauptschule, deretter tre år Gymnasiale Oberstufe som avsluttes med eksamen artium (Abitur), eller en yrkesutdannelse i en bedrift parallelt med yrkesskole (Berufschule).

${ }^{13}$ Det er viktig å understreke at 2. fremmedspråk kun er obligatorisk på Gymnasium, ikke på Realschule.

14 Det finnes ingen særskilte evalueringer av undervisningen i 2.fremmedspråk med fokus på starttidspunktet. Likevel formidler omtalen av undervisningen i den didaktiske litteraturen et inntrykk av at "man" er fornøyd med starttidspunktet og tilbudet for denne aldersgruppen.

15 Delstatene har ulike ordninger på dette punktet. Mittlerer Schulabschluss (MSA) som denne avgangseksamen kalles, oppnås i noen delstater etter 9. klasse, i andre etter 10. klasse. Dette vitnemålet kvalifiserer til de fleste yrkesutdanningene som ikke krever et studium. 


\section{Fasit for Tidlig start:}

Elevene tilbys et 2. fremmedspråk fra 6. klasse. Dermed har elevene anledning til å lære språket i syv (åtte) år før de avslutter videregående opplæring. Språkopplæringen er nokså tradisjonell og legger stor vekt på korrekt språkbruk. Elevene er motiverte til språklæring, og både de og lærerne ser ut til å være fornøyde med opplæringstilbudet. Etter videregående skole vil mange av elevene ha nådd nivået B1/B2.

\subsection{Fagundervisning på fremmedspråket $(C L I L)$}

I Tyskland finnes det stadig flere skoler som tilbyr fagundervisning på et fremmedspråk, såkalt content and language integrated learning (CLIL) (Lamsfuß-Schenk/Wolff 1999, Haataja 2009). Det mest vanlige er fagundervisning på engelsk (Wode 1996), men også i andre aktuelle fremmedspråk (f.eks. fransk, italiensk, dansk, polsk) (se også Zydatiß 2000). Tilbudet starter ofte allerede i barneskolen (Grundschule, 1.-4. klasse), mens det gjerne etableres egne linjer der flere fag undervises på fremmedspråket fra 5. klasse på gymnasene. Det finnes CLIL-skoler som opprinnelig ble etablert for å imøtekomme spesielle behov, som for eksempel Wolfsburg-prosjektet (tysk-italiensk, for barna til italienske arbeidere i Wolfsburg; Sandfuchs/Zumhasch 1999) eller Staatliche EuropaSchule Berlin, der man tilbyr ni språkkombinasjoner på ulike skoler for å ivareta språkmangfoldet i hovedstaden (tysk-engelsk, tysk-fransk, tysk-gresk, tysk-italiensk, tysk-polsk, tysk-portugisisk, tysk-russisk, tysk-spansk og tysk-tyrkisk). Ved disse skolene finner vi da som oftest barn med en flerspråklig bakgrunn, dvs. en eller begge foreldre har det aktuelle fremmedspråket som morsmål.

Men det finnes dessuten flere hundre skoler med CLIL-tilbud der man ikke bygger på en slik bakgrunn, dvs. at tilbudet retter seg kun mot elever som har tysk som morsmål. Tilbudene finnes hovedsakelig på gymnasene, mindre vanlige er slike tilbud for skoletypene Realschule og Hauptschule, men også de finnes.

Opplæringen starter eksempelvis med at elevene får ekstratimer i fremmedspråket i for eksempel 5. og 6. klasse. I disse timene legges det hovedsakelig vekt på praktisk språkbruk. Elevene skoleres i å uttrykke seg muntlig og skriftlig på språket, samt leser og hører fremmedspråklige tekster. I 6. klasse starter deretter undervisningen i ett eller flere skolefag på fremmedspråket.

Blant skolefagene foretrekkes det ofte samfunnsfag som historie, geografi, samfunnskunnskap og lignende. Dessuten finnes det skoler som satser på matematisknaturvitenskapelige fag (Helbig 2003, Thürmann 2000).

Vi har besøkt ulike skoler der CLIL ble gitt med undervisningsspråkene engelsk, fransk og italiensk, på ulike skoleslag (barneskole, gymnas, Gesamtschule), på ulike klassetrinn og ikke minst i ulike fag, samt den eneste CLILiG (=CLIL med tysk)-skolen i Nederland. Inntrykkene er varierte og mangfoldige. ${ }^{16}$ Viktigst er det å påpeke at elevene

\footnotetext{
${ }^{16}$ Det skal ikke underslås at bilingvale tilbud gjerne tiltrekker seg de faglig sterkeste elevene på samme måte som faglig sterke elever (og deres foreldre) bevisst velger skoler med litt mer spesielle undervisningstilbud.
} 
ser ut til å trives godt i timene, de er meget aktive og prøver å bruke fremmedspråket i både spørsmål og svar. Bruken av fremmedspråket i klasserommet føles naturlig, samtidig som morsmålet likevel har sin plass. Spørsmål, enkeltord og uttrykk på morsmålet er ikke bannlyste, men en naturlig del av læringsmiljøet. Lærerne responderer ved å hjelpe eleven på veg, ved for eksempel å stille nye og/eller nyttige uttrykk til rådighet, eller ved å forklare ting som ikke ble forstått. I samtalene med faglærerne bekreftes det at elevenes faglige kunnskaper ikke er dårligere enn det som forventes $\mathrm{i}$ undervisning utelukkende gitt på morsmålet. Samtidig har elevene uten tvil allerede fått en trygghet i forhold til egen språkbruk.

\footnotetext{
"Jeg har lært meg hvordan man sier sånne ting på engelsk. Hvordan vi sier det på tysk, det ser jeg jo i boka. Jeg prøver å si masse i timene. Det er aldri noen som flirer. Og sier man noe galt, retter Frau [...] det jo opp. Egentlig liker jeg til og med matte nå bedre enn tidligere.” (Jente, 10.klasse, matte på engelsk; oversettelse ved forfatterne)

"Man må lære mange ord og sånn. Ellers kan man jo ikke delta i diskusjonene. Men jeg har liksom lært meg å pugge gloser. Det føles på en måte sånn nyttig med de glosene. De er jo i de tekstene som vi leser, og så hører jeg dem i timene. Da kan jeg liksom lettere bruke dem.” (Gutt, 9.klasse, geografi på fransk; oversettelse ved forfatterne)
}

Elever som går på såkalte bilingvale linjer, dvs. at flere fag undervises på fremmedspråket, kjennetegnes ved at de har tilegnet seg enda større trygghet i omgang med språket enn de som kun har ett fag på fremmedspråket.

”Jeg har halvparten av mine fag på tysk, resten på nederlandsk. Jeg føler at jeg får sagt det meste på tysk. Jeg bruker tysk hver dag på skolen, jeg har vært på turer til Tyskland. Det er liksom et språk som engelsk [sic!] for meg."

(Nederlandsk gutt, tilsvarende 10. klasse, bl.a. matte, fysikk, kjemi på tysk; oversettelse ved forfatterne)

Det kan fastslås at selv bruken av språket i bare noen få timer ekstra per uke i kun ett fag har positiv innflytelse på elevenes omgang med språket. Dette bekreftes også av faglærerne.

De fleste skolene legger stor vekt på at de involverte lærerne har undervisningskompetanse i både språkfaget og i ikke-språkfaget. Lærerne virker svært engasjerte i undervisningsformen. De har ofte utarbeidet eget undervisningsmateriale og ser ut til å være flinke til å hanskes med de utfordringene denne typen undervisning gir. Men lærerne påpeker også at dobbelkompetansen ikke er alt som trenges, det kreves en helt egen didaktisk tilnærming.

”Jeg har undervist i fysikk og matte i mer enn ti år. I tillegg har jeg studert engelsk og undervist fagene mine i Storbritannia. Men dette her er noe helt annet. Jeg er heldig fordi jeg føler meg trygg i fagene og i språket. Og jeg vet hvordan det føles å lære engelsk. Jeg må liksom tenke på alt dette samtidig - og hele tida." (Lærer, matte og fysikk, gymnas; oversettelse ved forfatterne)

”Jeg er fransk og har jobbet som historielærer i Strasbourg. Nå bor jeg i Tyskland, har studert tysk og fransk [der] og underviser i historie på fransk. Det er på en måte verken det samme som historietimene i Frankrike eller historie på tysk i Tyskland. Det er så mye mer. [...] Ja, jeg har liksom mange ulike briller på i de timene. To språk, to kulturer som bakgrunn for undervisningen. Vi ser alt fra flere sider enn vanlig. [...] At vi bruker mye fransk, gjør det nesten lettere. Vi snakker mye om hva som egentlig står der i teksten og hvorfor. Også i de tyske tekstene. [...] Elevene 
lærer historie og fransk og på en måte å se på ting fra ulike sider. Det er krevende for meg og for elevene, men jeg liker det utrolig godt." (Lærer, historie, fransk og tysk som andrespråk, gymnas; oversettelse ved forfatterne)

Ved flere av skolene har CLIL-lærerne organisert seg som en arbeidsgruppe. De samarbeider med tanke på arbeidsmateriell, tilrettelegging av lærestoff, undervisningsplanlegging, utarbeidelse av tester o.l. Ved noen av skolene tilbys det til og med språktrening, dvs. et frivillig tilbud med en morsmålsbruker for å kunne styrke egne språklige ferdigheter.

\section{Fasit for CLIL:}

Fagundervisning på fremmedspråk (CLIL) tilbys gjerne til elever som allerede har forkunnskaper i språket f.eks. fordi de har foreldre eller besteforeldre som har språket som morsmål, eller fordi de har bodd i et land der språket brukes. For øvrig ser det ut som om tilbudet tiltrekker seg særlig interesserte og/eller faglig sterke elever. Det at tilbudet fortrinnsvis gis på Gymnasium, tyder også på at denne formen for språkundervisning anses som krevende og ikke nødvendigvis egner seg for alle. Undervisningstilbudet krever dessuten lærere med dobbelkompetanse, i både fremmedspråket og ikkespråkfaget.

Likevel må det kunne slås fast at de elevene som går på CLIL-linjer eller får CLIL-undervisning i ett eller flere fag, ser ut til å oppnå svært gode språkferdigheter uten at dette går på bekostning av kunnskapene i det aktuelle skolefaget. Elevene forteller dessuten at de føler en stor trygghet i forhold til språket og har lettere for å ta språket aktivt i bruk.

\subsection{Aktivitetsgrupper (AGer)}

Mange skoler tilbyr undervisning i et 3. eller 4. fremmedspråk etter at den "vanlige" skoledagen er slutt. Ettermiddagsaktivitetene er ikke nødvendigvis av språklig art, dvs. det finnes også AGer innenfor diverse idretter, kor og lignende. Fremmedspråk eller morsmål/andrespråk er dermed kun en del av tilbudet. Særlig i byene finnes det ofte et utstrakt samarbeid mellom skolene, slik at det ved hjelp av arbeidsdeling kan tilbys mange språk. En modell går ut på at språkene fordeles mellom skolene, mens undervisningen er åpen for elevene fra alle skolene i byen. Rektorene og lærerne forteller at dette er populære tilbud, der den enkelte skolens ansvar for "sitt/sine" språk sikrer tilgang til god og kontinuerlig lærerkompetanse. Elevene møtes ved den aktuelle skolen en ettermiddag i uken. Denne kompakte løsningen er etter utsagn fra rektorene en viktig organisatorisk forutsetning for å kunne sikre elevenes interesse over tid. De fleste faglærerne kunne ønske seg undervisning to ganger i uken, men innser at dette også vil kunne slå negativt ut. Som positive moment trekkes det fram at det oppstår gode samarbeidsgrupper bestående av høyt motiverte elever. Ingen tvinges til å velge et bestemt språk, men det store elevgrunnlaget i en by sikrer at også kurs for mindre språk får nok deltakere. 
"Jeg underviser i polsk. I de første årene deltok nesten bare elever med familiære bånd til Polen. Men i de siste 5-6 årene kommer det elever som rett og slett bare liker å lære polsk og om polske forhold." (Lærer; polsk, engelsk, fransk, russisk; gymnas; oversettelse ved forfatterne)

"Vi blir godt kjente med hverandre. Timene er veldig trivelige. Elevene er nesten aldri borte. Er de syke, ringer eller mailer de dagen etter. Jeg elsker disse timene, selv om torsdagen dermed blir en veldig lang arbeidsdag for meg."

(Lærer; japansk, matte, fysikk; gymnas; oversettelse ved forfatterne)

Andre steder har man utnevnt en av skolene som "språksenter" (Sprachenzentrum). Denne skolen er da byens knutepunkt-skole for fremmedspråk. En ettermiddag i uken er avsatt til språkkursene, og elever fra hele byen kan delta. Også dette tiltaket er populært. Likevel viser tallene at flesteparten av deltakerne kommer fra tilbyder-skolen. Samtidig skal det ikke underslås at tilbyder-skolen gjerne profilerer seg som en skole som satser på språk, gjerne som såkalt Europaschule ${ }^{17}$. Dermed tiltrekker skolen seg elever som ønsker å lære flere og mer sjeldne fremmedspråk. Lærerne oppfatter særlig muligheten til kollegialt samarbeid i en stor fremmedspråklærergruppe som veldig givende.

"Vi er på en måte en gruppe kolleger som underviser på torsdagsettermiddager. Vi underviser i mange ulike språk, men opplevelsene, tankene osv. er ganske like. Det gir mye å utveksle idéer og lignende. Elevene som er her på torsdager, ser på dette nesten som å gå på en idretts-øving. [...] Vi rekker mye, jobber veldig praktisk og har det veldig gøy. Klokka tre om ettermiddagen er ting liksom litt annerledes."

(Lærer; japansk, matte, fysikk; gymnas; oversettelse ved forfatterne)

AGene ser ut til å jobbe ganske fritt. Lærerne føler at de får fokusere mer på praktisk språkbruk og språkglede. Etter to, tre års opplæring vil elevene etter endt 10. klasse ha oppnådd nivå $\mathrm{A} 2 / \mathrm{B} 1$, etter kontinuerlig undervisning gjennom tre år på videregående skole er til og med B2 et realistisk kompetansemål.

\section{Fasit for fremmedspråks-AGer:}

Fremmedspråks-AGer har sin styrke i det at kun motiverte elever vil benytte seg av slike tilbud som foregår etter skoletid. Dermed vil motivasjonsgrunnlaget i de fleste språkgruppene være langt bedre enn $i$ et tradisjonelt undervisningstilbud for alle. Undervisningen foregår litt "utenfor" den vanlige undervisningen og er derfor ikke så strengt knyttet opp mot fagplaner. Tilbudet krever selvsagt kompetente lærere som stiller opp etter ordinær undervisningstid, men gjerne lærere som klarer å tilby en litt annen type undervisning enn den tradisjonelle. ${ }^{18}$ Ofte møter slike ettermiddagstilbud noen utfordringer i form av organisering, sted og tidspunkt. Bredden i tilbudet er til en hver tid avhengig av tilgangen til kompetente lærere og interesserte elever på det aktuelle stedet.

\footnotetext{
${ }^{17}$ Europaschulen har en egen europeisk dimensjon i læringsinnholdet. De skal støtte elevene i det å være borgere i et europeisk fellesskap. Språkopplæring er kun en del av dette anliggende. Det finnes mange ulike skoletyper blant Europaschulen, bl.a. også flere yrkesskoler (Europaschulen, Europäisches Curriculum 2010, 8). Se for eksempel http://www.schulministerium.nrw.de/BP/Schulsystem/Schulformen/ Europaschulen/ eller www.europaschulen.de .
}

${ }^{18}$ Dette punktet kommer vi tilbake til i kapittel 4. 


\subsection{Fremmedspråkundervisning på yrkesskolene}

Ved yrkesskolene ${ }^{19}$ blir vanligvis kun det første fremmedspråket engelsk tilbudt (Funk 1992, 2003; Ross 1997). Fremmedspråkundervisningen er veldig yrkesrettet og forbereder til en sertifisering etter europeiske normer (KMK-Fremdsprachenzertifikat $)^{20}$. Ved noen yrkesskoler, såkalte yrkesfaglige gymnas (Berufliche Gymnasien) ${ }^{21}$, stilles det også krav til et 2. fremmedspråk. Som oftest tilbys det fransk og/eller spansk, men også kinesisk er blant de språkene det satses på. Ved disse yrkesfaglige gymnasene opprettes det gjerne også en klasse med bilingval profil, dvs. at undervisningen i flere av fagene gis på engelsk (CLIL).

Siden yrkesskolene opererer med mindre faste rammer for undervisningstilbudene enn for eksempel gymnasene, åpner det seg muligheter for flere typer yrkesrettede kurs.

"I vår avdeling for restaurantfag tilbyr vi språkkurs i yrkesrettet fransk. Tilbudet går over 2 timer per uke og er frivillig, men de som deltar får et sertifikat og kan søke om å bli med på vår studietur til Frankrike. Fransk er veldig nyttig, og de fleste elevene liker faget godt." (Lærer; restaurantfag, underviser i yrkesrettet fransk; yrkesskole; oversettelse ved forfatterne)

"Vi tilbyr nå et tsjekkisk-kurs for våre elever. Vi jobber tett sammen med skoler og bedrifter $\mathrm{i}$ Tsjekkia. Er jo like over grensa. Da er det greit å kunne litt. [...] Elevene på de to tsjekkiske skolene lærer tysk, og vi har sånn kontakt via nettet. Hver klasse har en sånn partnerklasse. De lærer oss bedre tsjekkisk, og vi lærer dem tysk. Det er veldig populært. [...] Det hjelper nå på å få bedre kontakt med hverandre. Mange har mistet fordommene sine etter dette her." (Lærer; metallog fartøyteknikk; yrkesskole; oversettelse ved forfatterne)

Det tilbys altså kurs som tar opp språk som vil kunne være nyttige for elevene med tanke på yrkene de utdanner seg til. Språkopplæringen er yrkesrettet og kombineres gjerne med en studietur eller en form for elevutveksling.

\section{Fasit for fremmedspråkundervising på yrkesskolene}

Det er ikke så mange yrkesforberedende skoler som tilbyr elevene undervisning i et 2 . fremmedspråk. Men de skolene som gjør det, kan fortelle om svært vellykkede prosjekter. Språkundervisningen er tilpasset den yrkesutdannelsen elevene får og er ofte også knyttet opp mot utvekslingsprogram og lignende.

19 Yrkesskole brukes her som en oversettelse for tyske skoletyper som kaller seg for Berufliche Schule, Berufsschule og lignende. Begrepene omfatter på den ene siden skoler som følger opp ungdom som tar en yrkesutdannelse i en bedrift, på den andre siden skoler som gir en yrkesforberedende utdannelse innenfor ulike områder. Flere av disse sistnevnte kan i sin struktur sammenlignes med norske videregående skoler som tilbyr yrkesforberedende utdanningsprogrammer.

${ }^{20}$ Mange skoler tilbyr elevene denne sertifiseringen, men elevene tvinges ikke til denne evalueringen.

21 Flere av disse skolene kan sammenlignes med norske videregående skoler med yrkesforberedende utdanningsprogrammer. Utdanningsprofilene ligger innom områdene elektrofag, teknikkfag, kjemi-/fysikkfag, økonomi, helse og lignende. 


\section{Overføringsmuligheter til norske forhold}

Utdanningssystemer og deres konkrete omsetting i praksis gjenspeiler alltid samfunnet og rammevilkårene for utdanning og arbeidsliv i det aktuelle landet. Derfor vil deler av et utdanningssystem heller ikke kunne overføres til et annet land uten en form for tilpasning. Vi ønsker nå å se på de mer utradisjonelle undervisningstilbud i fremmedspråk som vi har presentert ovenfor, med tanke på om og på hvilken måte disse vil kunne la seg overføre til norske forhold. Tilbudene vurderes i denne sammenhengen som supplementer til den tradisjonelle fremmedspråkundervisningen på skolen, ikke som en erstatning. Fokuset vårt rettes altså mot vårt hovedanliggende - åpningen for flere og annerledes veger $i$ fremmedspråkopploringen.

\subsection{Tidlig start med 2. fremmedspråk}

Prosjektet Forsøk med tidlig start med 2.fremmedspråk er allerede godt i gang ved flere pilotskoler i Norge. ${ }^{22}$ Prosjektet følger opp et tidligere Forsøk med tidlig start fra 2005-2007.23 Begge prosjektene ser ut til å være vellykkede (Speitz/ Simonsen/Streitlien 2007; Mordal/Lindemann/Aaslid 2012 a og b). Elevene liker å lære språk allerede på barneskolen, og språklæringsgleden er svært stor også i Norge (Mordal/Lindemann/ Aaslid $2012 \mathrm{a} \mathrm{og} \mathrm{b).} \mathrm{Innføringen} \mathrm{av} \mathrm{faget} \mathrm{2.} \mathrm{fremmedspråk} \mathrm{på} \mathrm{barneskolen} \mathrm{vil} \mathrm{møte} \mathrm{en}$ del utfordringer (se nedenfor), men vil ha sine fortrinn først og fremst $i$ det at elevene starter med språklæringen mens de er meget motiverte for det. En start allerede i 6. klasse gjør det mulig å lære språket i syv (åtte ${ }^{24}$ ) år og dermed kunne oppnå langt bedre språkkunnskaper enn nå. Prøveprosjektene har vist at tidlig fremmedspråkundervisning vil kunne innføres i Norge.

\subsection{Fagundervisning på fremmedspråket (CLIL)}

Fagundervisning på et fremmedspråk er inntil nå heller ukjent i Norge. ${ }^{25}$ Det finnes noen skoler som tilbyr fagundervisning på engelsk. ${ }^{26}$ I tillegg finnes det forsøk med

\footnotetext{
22 Se linken til prosjektet: http://www.fremmedspraksenteret.no/nor/fremmedspraksenteret/fremmedsprakpa-barnetrinnet-1/fremmedsprak-pa-barnetrinnet , 13.1.2012. Der finnes også første delrapport fra evalueringsinstansen SINTEF.

${ }^{23}$ Se linken til prosjektet: http://www.fremmedspraksenteret.no/nor/fremmedspraksenteret/fremmedsprak-pa-barnetrinnet-1/tidligereprosjekter, 13.1.2012.

24 Åtte år for de av elevene som velger å ta et fordypningsår.

${ }_{25}$ Vi ser her bort fra undervisningen på privatskoler, beregnet på elever med internasjonal bakgrunn, som for eksempel Den internasjonale skolen i Stavanger, Den tyske skolen i Oslo og lignende.

26 Se oversikten over skolene på Fremmedspråksenterets hjemmeside www.fremmedspraksenter.no , 13.1.2012.
} 
tyskspråklig undervisning innenfor prosjektet CLILiG-SCAN ${ }^{27}$. Ved to videregående skoler i Tromsø med yrkesforberedende utdanningsprogrammer tilbys det yrkesrettet fagundervisning på tysk, og ved noen barneskoler i Tromsø tilbys det prosjektuker med fagundervisning på tysk og norsk i utvalgte fag ved hjelp av tyskspråklige språkassistenter. Prosjektene må sies å være vellykkede, men viser med all tydelighet at det kreves en større og mer stabil satsning på området (for eksempel Lindemann 2006a og b, 2009).

Skal det kunne tilbys fremmedspråklig fagundervisning på ungdomsskolene og de videregående skolene, må fremmedspråkundervisningen i 8. og 9. klasse styrkes (for de elevene det gjelder) for å kunne bygge opp et språklig grunnlag for fagundervisningen. Tilbud om ett eller flere fag på fremmedspråket i 9. og 10. klasse for en gruppe elever som velger dette selv, vil kunne bidra til at elevene oppnår langt bedre språklige ferdigheter etter endt ungdomsskole enn tidligere, uten at dette går på bekostning av kunnskapene i andre fag. ${ }^{28}$ Men en overføring til norsk skole vil være avhengig av en styrket språkundervisning i skoleåret forut for innføringsåret og lærere med dobbelkompetanse.

\subsection{Arbeidsgrupper}

Arbeidsgrupper etter skoletid finnes allerede ved noen skoler. Ved barneskolene er disse ofte hobby-pregede, av og til i regi av SFO eller elevenes foreldre. Da man på 80- og 90tallet hadde mange valgfagstilbud på ungdomsskolene, var det vanlig at elevene møttes en ettermiddag i uka for å øve på traktorkjøring og lignende. Å etablere ettermiddagskurs i fremmedspråk vil altså ikke være en umulighet. Særlig på større steder vil kursene kunne organiseres slik at enkelte skoler får knutepunktfunksjonen for alle språktilbudene eller for bestemte språk. Et tett internt samarbeid mellom alle de aktuelle skolene på stedet vil kunne åpne for en fast "språkettermiddag" som tilbys av skolen(e) på lik linje med kulturtilbudene fra kommunens kultur- eller musikkskole. ${ }^{29}$ Men også på mindre steder finnes det ofte ressurspersoner med god kompetanse i ulike språk.

\footnotetext{
27 Prosjektet CLILiG-SCAN er et fellesnordisk prosjekt med fokus på tyskspråklig fagundervisning. Prosjektet har utarbeidet et nettbasert EVU-kurs for CLILiG-lærere og initierer og følger opp CLILiGprosjekter ved nordiske skoler. Knutepunkt i Finland er Universitetet i Tampere. I Tampere by har man etter hvert lang erfaring med tyskspråklig fagundervisning fra barneskolen til eksamen artium. Det svenske knutepunktet er Göteborgs universitet. Også i Göteborg finnes det flere "gymnas" som tilbyr fagundervisning på tysk. I Danmark er samarbeidspartneren Roskilde Universitetscenter (RUC). Det finnes per i dag ingen offentlige skoler med et tyskspråklig undervisningstilbud, men RUC og Fredriksberg Seminarium samarbeider om å sette i gang pilotprosjekter. Prosjektet ledes fra Universitetet i Tromsø. I Tromsø finnes da også pilotskolene som prosjektet samarbeider med.

${ }^{28}$ Se for eksempel Lamsfuß-Schenk 2008 og Zydatiß 2007. Samtidig må det påpekes at det trenges langt flere forskningsbaserte evalueringer av CLIL-undervisning der man undersøker aspekter som elevenes språklige og faglige kunnskaper og ferdigheter.

${ }^{29}$ I sin tid var det for øvrig slik engelskundervisning ble igangsatt, som frivillig ettermiddagsundervisning for gutter i sørlandsbyene som hadde sterk rekruttering til sjømannsyrket og handel med Storbritannia (Ytreberg 1993).
} 
Arbeidsgruppetanken innbyr til praktisk rettet undervisning som setter fokus på språket i bruk. Språklæringsgleden og elevenes aktive holdning til språkbruk vil derfor måtte stå $i$ sentrum for opplæringen. Innblikkene fra de tyske fremmedspråks-AGene har vist at kursene utelukkende blir valgt av svært motiverte elever som har valgt fremmedspråket på samme måte som en idrett eller et musikkinstrument. Man kan anta at dette $\mathrm{i}$ utgangspunktet ikke vil forholde seg annerledes i Norge. Likevel kan man ikke lukke øynene for at norske elever flest anser språkkunnskaper utover engelskkunnskapene som overflødige (som nevnt i innledningen). Skal rekrutteringen kunne lykkes, vil det derfor kreve en god del arbeid med tanke på holdningsendringer.

\subsection{Fremmedspråkundervisning på yrkesforberedende utdanningsprogrammer}

Norske yrkesforberedende utdanningsprogrammer inneholder per i dag kun undervisning $i$ yrkesrettet engelsk. Ved flere utdanningsprogram vil undervisningen $i$ et 2 . fremmedspråk være nyttig både med tanke på selve utdanningen og det framtidige yrkeslivet til eleven. Forsøkene med tyskspråklig fagundervisning ved undervisningsprogram innenfor hotell- og næringsmiddelfag og reiseliv ${ }^{30}$ har vist at fremmedspråkundervisningen, og de ferdighetene og kunnskapene som kan tilegnes der, oppfattes som svært nyttige også av elevene selv. I hospiteringsperiodene får de yrkesfaglige elevene stadige bekreftelser på at det kreves gode ferdigheter i flere språk enn engelsk i de yrkene de ønsker å utdanne seg til. Yrkesrettet språkundervisning, for eksempel også i form av CLIL, formidler til elevene de språklige ferdighetene de har bruk for. Undervisningen fokuserer samtidig alltid på språket i bruk, dvs. i kommunikasjonen med brukere som har språket som morsmål eller bruker det som lingua franca. Dermed formidles det samtidig en grunnleggende interkulturell forståelse for (språklig) samhandling med andre.

Dagens europeiske utvekslingsprogram, særlig også for elever i yrkesrettede utdanningsprogrammer, innbyr til utstrakt samarbeid med utenlandske utdanningsinstitusjoner og bedrifter. For å kunne utnytte slike tilbud trenger elevene en grunnleggende språklig kompetanse og innsikt i hverdagskulturen i de landene man samarbeider med. Yrkesrettet fremmedspråkundervisning setter praktisk språkbruk i sentrum for opplæringen. Elevenes språklæring knyttes tett til innsikt i aspekter ved målspråkkulturen som vil være relevante for elevene i deres yrkesframtid.

\section{Utfordringer på vegen}

Gjennomgangen av de alternative og supplerende undervisningstilbudene med tanke på omsetting innenfor et norsk opplæringssystem har vist at tilbudene vil kunne settes ut $\mathrm{i}$ praksis også i Norge. Samtidig ble det tydelig at disse opplæringstilbudene vil føre en del utfordringer av ulik art med seg. Disse skal vi nå se litt nærmere på.

\footnotetext{
${ }^{30}$ Se også kapittel 4.2.
} 


\subsection{Adekvat utdanning for lærerne}

\section{a) Undervisning på barneskolen}

Undervisning $\mathrm{i}$ et 2 . fremmedspråk på barneskolen krever lærere som både har god språkkompetanse og didaktisk kompetanse med tanke på fremmedspråkundervisning for denne aldersgruppen (Bausch/Christ/Krumm (Hrsg.) 1990, Bausch/Christ/Krumm 2003, Maier 1991, Rück 2004). 2. fremmedspråk bør derfor bli ett av fagene som tilbys innenfor den nye lærerutdanningen (her: Integrert lærerutdanning 1.-7.). Faget "2. fremmedspråk", dvs. de språkfagene som tilbys som mulige undervisningsfag for barneskolen, bør ved siden av den språklige og språkpraktiske opplæringen alltid inneholde didaktiske momenter rettet inn mot den aktuelle aldersgruppen (for eksempel Chighini/Kirsch 2009). Undervisningen på dette nivået legger et viktig grunnlag både for fremtidig læring av det aktuelle språket og dessuten for læringen av ytterligere fremmedspråk. Kun godt skolerte lærere vil kunne lykkes i å styrke elevenes språklæringsmotivasjon og i å holde språklæringsgleden ved like. "Dårlige erfaringer" vil prege eleven(e)s tanker omkring egen språklæring i lang tid framover og vil i verste fall føre til at elevenes dører til fremmede språk og kulturer forblir uåpnede.

\section{b) CLIL-undervisning}

Også CLIL-undervisningstilbud krever lærere som er godt utdannede til nettopp dette formålet. Ved siden av deres undervisningskompetanse i fag som historie eller matte må de ha gode språkkunnskaper, helst også undervisningskompetanse i språkfaget. I tillegg kreves det uten tvil didaktisk kompetanse rettet mot de spesielle utfordringene CLIL-undervisningen fører med seg. Flere av institusjonene som utdanner lærere i for eksempel Tyskland og Nederland, tilbyr nå også (etter- og videreutdannings-) moduler innenfor CLIL for å forberede lærerstudentene til denne nye typen undervisning. ${ }^{31}$ Skolene oppfatter denne kompetansen som en viktig tilleggskompetanse. Flere rektorer opplyste om at de vektla en slik kompetanse ved nytilsettinger for å kunne tilby "moderne undervisning". CLIL-moduler ved noen av lærerutdanningsinstitusjonene i Norge vil kunne åpne for en slik kompetanseutvikling også her i landet.

Om CLIL-kompetansen til læreren er høy nok og ikke minst adekvat, er av avgjørende betydning for kvaliteten av det tilbudet elevene kan få. CLIL-tilbudet må både faglig og språklig være tilpasset den elevgruppen det skal rette seg til. Det er viktig å understreke at det ikke kreves $\mathrm{C} 1 / \mathrm{C} 2$-kompetanse i fremmedspråket av alle faglærerne som skal undervise faget sitt på et fremmedspråk. Samtidig er meget gode språkkunnskaper ingen garanti for at CLIL-tilbudet blir vellykket. Men når både fag- og språkkunnskaper er på plass på et nivå som ser ut til å passe for det aktuelle undervisningstilbudet, vil vedkommende ved hjelp av en adekvat didaktisk skolering være godt forberedt for de oppgavene som venter.

\section{c) Undervisning i arbeidsgrupper}

Når det gjelder språkundervisningen i arbeidsgruppene etter skoletid, vil hovedtyngden av tilbudene ligge på nybegynneropplæring i ulike, muligens litt "eksotiske" språk.

\footnotetext{
${ }^{31}$ CLIL-moduler tilbys for eksempel ved universitetene i Bochum, Bremen, Wuppertal, Bonn, Frankfurt am Main, Göttingen og Trier.
} 
Derfra sluttes det ofte at lærerne ikke trenger å ha "så gode språkkunnskaper" som f.eks. lærere på et videregående språkopplæringstrinn. Men forskningen både innenfor fremmedspråkopplæring generelt og didaktisk forskning har vist at særlig nybegynneropplæring stiller store krav til både språklige og didaktiske ferdigheter hos den som underviser. Uten tvil kreves det gode og trygge språkkunnskaper og gode didaktiske kunnskaper og ferdigheter. Arbeidsgruppene vil kjennetegnes ved at de arbeider frivillig og etter skoletid. Samtidig vil de i hovedsak trekke til seg elever med en genuin interesse for å lære det aktuelle språket. Det kreves derfor lærerpersonell som er flink til å utnytte disse faktorene til fordel for språklæringen og til å opprettholde elevenes språklæringsmotivasjon over tid.

\section{d) Undervisning på yrkesrettede utdanningsprogrammer}

Fremmedspråkundervisning på yrkesrettede utdanningsprogrammer vil måtte skille seg tydelig fra fremmedspråkundervisning på de studieforberedende programmene. Yrkesrettet språkundervisning krever lærere som ikke bare har erfaring som fremmedspråklærere, men også innblikk i den aktuelle yrkesutdannelsen. Ofte vil yrkesfaglærere med utenlandserfaring ha et godt grunnlag for å kunne påta seg denne typen undervisning. Etter- og videreutdanningskurs for yrkesfaglærere med tanke på denne typen spesialkompetanse vil kunne sørge for den nødvendige språklige og didaktiske tryggheten.

\subsection{Adekvate læremidler}

\section{a) læremidler til barneskolen og til aktivitetsgrupper}

Undervisningen i 2.fremmedspråk på barneskolen krever gode læremidler på lik linje med andre fag i barneskolen (for eksempel Neuner 2003). Læremidlene må være tilpasset elevenes alder og språklige ferdighetsnivå. Lærebøker laget for ungdomsskoleelever er som oftest uegnete. Siden det per i dag ikke finnes lærebøker for 2. fremmedspråk på barnetrinnet fra de etablerte norske skolebokforlagene, lager de fleste lærerne sitt eget materiale og støtter seg for eksempel til læremidler utviklet for tidlig engelskundervisning. Andre henter inspirasjon i lærebøker for det aktuelle språket fra andre land der språket tradisjonelt allerede undervises på dette alderstrinnet. Dette gir ofte mer helhetlige løsninger for større undervisningsenheter og avlaster i tillegg faglæreren. Fokuset på kursets kontinuerlige kompetanseutvikling og progresjon er viktig og holdes vanligvis lettest ved hjelp av en lærebok. Språkundervisningen på barneskolen har selvsagt fastsatte kompetansemål som skal oppnås og må ikke misoppfattes som et sammensurium av ulike "morsomme språklige aktivitetsprosjekt". ${ }^{32}$ Etter en viss innførings- og innkjøringsfase burde det kunne utvikles læremidler som er tilrettelagt for ulike elevgrupper i den norske barneskolen.

Også aktivitetsgruppene trenger læremidler tilrettelagt for formålet. Tradisjonelle lærebøker kan lett føles uegnete fordi de legger opp til tradisjonell undervisning og langt flere undervisningstimer per uke enn slike kurs kan rå over. Svært ofte vil hovedfokus i

32 Se også kompetansemålene i læreplanene for fagene under forsøket: http:// www.fremmedspraksenteret.no/nor/fremmedspraksenteret/fremmedsprak-pa-barnetrinnet-1/fremmedsprakpa-barnetrinnet, 13.1.2012. 
lærebøkene ligge på skriftlig språkbruk, mens språkkurset ønsker å sette muntlig språkbruk i fokus. Aktivitetsgruppene danner gjerne en ny type elevgruppe som det til nå ikke finnes egnede læremidler for.

\section{b) læremidler for CLIL og yrkesrettet undervisning}

Fremmedspråklig fagundervisning og yrkesrettet språkundervisning krever gode læremidler som egner seg språklig og faglig for den aktuelle elevgruppen. Tilgangen til gode fremmedspråklige læremidler kan imidlertid være vanskelig. Skolebøker beregnet for morsmålsbrukere fra målspråklandet er i mange tilfeller uegnete, fordi de både er språklig sett for avanserte for elevene og fordi de samtidig tar utgangspunkt i en kulturell grunnforståelse som elevene ikke kjenner til. Skolene forteller at de som oftest har gjort de beste erfaringene når de har supplert lærebøkene på morsmålet med tilpasset fremmedspråklig materiale eller med fremmedspråklige læremidler fra andre land der det tilbys CLIL-undervisning eller yrkesrettet språkundervisning. Norskspråklige læremidler kan og bør selvsagt være et viktig supplement. Valget av adekvate læremidler vil uten tvil være en utfordring for alle lærerne som starter opp med denne typen fagundervisning. Gode nettverk mellom de aktuelle lærerne og en oppbygging av en læremiddel-pool der materialene og tilretteleggingsarbeidet kan deles, vil kunne bidra til å lette både innføringen og gjennomføringen av slike prosjekter.

\subsection{Overgang til og fra opplæringstilbudet}

Velger man å supplere undervisningstilbudene i fremmedspråk utenom engelsk med noen av de skisserte alternative opplæringstilbudene, vil dette kreve at overgangen til og fra opplæringstilbudet tilrettelegges i tråd med behovene.

Skal man for eksempel tilby faget "2. fremmedspråk" på barneskolen, må det tilrettelegges for mottaksklasser på de aktuelle ungdomsskolene. I ungdomsskolen må elevene tilbys fremmedspråkundervisning for viderekomne i det språket de lærte på barneskolen. Ingen må presses til å måtte velge et nytt 2 . fremmedspråk eller å starte forfra $i$ en nybegynnergruppe. Kun en tilpasset videreføring av språkundervisningen fra barneskolen vil kunne være et tilfredsstillende tilbud som bidrar til å øke elevenes språkkunnskaper og styrker deres trygghet med tanke på adekvat bruk av fremmedspråket. Innføringen av fremmedspråkfaget på barneskolen vil derfor kreve et tett samarbeid med den ungdomsskolen elevene sokner til, slik at tilbudene for begge skoletypene er kompatible. ${ }^{33}$

På samme måte vil fremmedspråklig fagundervisning (CLIL) og yrkesrettet språkundervisning være tjent med at elevene som skal benytte seg av disse tilbudene, gis en grunnleggende språkundervisning på forhånd. Dette vil for eksempel kunne innebære

\footnotetext{
33 Problemet er dessverre allerede meget velkjent fra overgangen fra ungdomsskolen til videregående skolen På ungdomsskolene tilbys elevene fremmedspråk som ikke kan følges opp av de videregående skolene elevene vanligvis sokner til. Dermed blir elevene tvunget til å avbryte språklæringen i deres 2 . fremmedspråk og starte mot eget ønske med et 3. fremmedspråk på den videregående skolen. For de fleste elevenes vedkommende går deretter ferdighetene i det 2. fremmedspråket, som elevene jo har tilegnet seg i tre år, i glemmeboken.
} 
at elevene opplyses om at inntaket til et bestemt yrkesforberedende utdanningsprogram krever grunnleggende språkopplæring i et fastlagt språk fra ungdomsskolen, eller at dokumentert språklæring i det aktuelle språket åpner for deltakelse i CLIL-tilbud.

I motsetning til dette bør det ikke kreves forkunnskaper for deltakelse i nybegynneropplæring $\mathrm{i}$ aktivitetsgruppene, slik at tilbudet ikke $\mathrm{i}$ realiteten blir en morsmålsopplæring for minoritetsgrupper. Aktivitetsgruppene har sin misjon $\mathrm{i}$ å henvende seg i utgangspunktet til elever med en særskilt interesse for et språk - uten at familiære bånd skal være påkrevde.

\section{Et kort blikk på fremtida}

Bidraget har innledningsvis presentert noen eksempler på alternative organiseringsmåter for fremmedspråkopplæring slik de blir praktisert ved mellomeuropeiske skoler. I den andre delen av bidraget ble overføringsmulighetene for disse opplæringsmodellene til en norsk skolevirkelighet vurdert. Det ble konstatert at tilbudene vil kunne egne seg til norske forhold og at det vil følge en del utfordringer - men ingen uoverkommelige - i kjølvannet av disse.

Norsk skole tilbyr i dag undervisning i engelsk fra 1 . klasse og $i$ et 2 . fremmedspråk fra 8 . klasse. Opplæringen i et 2. fremmedspråk er ikke obligatorisk på ungdomsskolen, og faget blir først obligatorisk fra vg1 for elever på studieforberedende utdanningsprogrammer på de videregående skolene. Erfaringene viser at svært mange elever avslutter sin skolegang praktisk talt uten eller med mangelfulle fremmedspråkkunnskaper (med unntak av engelsk). Ser vi bort fra elevene som velger språklig fordypning (nivå III) på vg3, ligger elevenes kunnskaper etter vg3 på ikke mer enn A1 eller A2-nivå (etter den felleseuropeiske referanserammen). Norske elever havner dermed i gruppen av europeisk ungdom som har dårligst kompetanse i 2. fremmedspråk. Mange oppnår dermed ikke målene Europarådet ${ }^{34}$ har satt om at europeiske borgere bør beherske to fremmedspråk ved siden av deres morsmål.

Dermed svekkes i Norge både den enkelte elevens muligheter til å kvalifisere seg for mer internasjonalt rettede jobber utenfor Norge og norske bedrifters konkurranseevne med tanke på kontakten med de viktigste handelspartnerne. Istedenfor vår tradisjonelle språkundervisning vil en bred satsning på supplerende tilbud innenfor fremmedspråk - i tråd med målene i St.meld. nr 23 Språk bygger broer - kunne sørge for mer målrettede tilbud som setter sterkere fokus på enkeltelevens språklige interesser, ferdigheter, behov og muligheter.

Beate Lindemann og Annelise Brox Larsen Universitetet $i$ Tromsø

34 Se også Språk åpner dører 2007, 8. 


\section{Referanser}

Bausch, Karl-Richard / Christ, Herbert / Krumm, Hans-Jürgen (Hrsg.)(1990): Die Ausbildung von Fremdsprachenlehrern: Gegenstand der Forschung. Bochum (2.Auflage 1992).

Bausch, Karl-Richard / Christ, Herbert / Krumm, Hans-Jürgen (2003): Ausbildung von Fremdsprachenlehrern an Hochschulen. I: Bausch, Karl-Richard / Christ, Herbert / Krumm, Hans-Jürgen (Hrsg.) (2003): Handbuch Fremdsprachenunterricht. Tübingen: A.Francke (4. völlig überarbeitete Auflage), 475-481.

Bausch, Karl-Richard / Helbig, Beate (2003): Erwerb von zweiten und weiteren Fremdsprachen im Sekundarschulalter. I: Bausch, Karl-Richard / Christ, Herbert / Krumm, Hans-Jürgen (Hrsg.) (2003): Handbuch Fremdsprachenunterricht. Tübingen: A.Francke (4. völlig überarbeitete Auflage), 459-464.

Bleyhl, Werner (2000): Fremdsprachen in der Grundschule. Hannover: Schroedel.

Chighini, Patricia / Kirsch, Dieter (2009): Deutsch im Primarbereich. Berlin et al: Langenscheidt.

Christ, Herbert (1999): In zwei Sprachen: ein Schulversuch in Frankfurt am Main. Zeitschrift für Interkulturellen Fremdsprachenunterricht 4,2; http://zif.spz.tudarmstadt.de/jg-04-2/beitrag/christh2.htm , 24.1.2012.

Christ, Herbert (2003): Erwerb von Fremdsprachen im Vorschul- und Primarschulalter. I: Bausch, Karl-Richard / Christ, Herbert / Krumm, Hans-Jürgen (Hrsg.) (2003): Handbuch Fremdsprachenunterricht. Tübingen: A.Francke (4. völlig überarbeitete Auflage), 449-454.

Fröhlich-Ward, Leonora (2003): Fremdsprachenunterricht im Vorschul- und Primarbereich. I: Bausch, Karl-Richard / Christ, Herbert / Krumm, Hans-Jürgen (Hrsg.) (2003): Handbuch Fremdsprachenunterricht. Tübingen: A.Francke (4. völlig überarbeitete Auflage), 198-202.

Europaschulen, Europäisches Curriculum 2010

Funk, Hermann (1992): Berufsbezogener Deutschunterricht. Fremdsprache Deutsch, Sondernummer, 4-15.

Funk, Hermann (2003): Berufsbezogener Fremdsprachenunterricht. I: Bausch, KarlRichard / Christ, Herbert / Krumm, Hans-Jürgen (Hrsg.) (2003): Handbuch Fremdsprachenunterricht. Tübingen: A.Francke (4. völlig überarbeitete Auflage), 175-179.

Haataja, Kim (2009a): Integriertes Sprach- und Fachlernen (CLIL). I: Barkowski, Hans / Krumm, Hans-Jürgen (2009)(Hrsg.): Fachlexikon Deutsch als Fremd- und Zweisprache. Tübingen: Narr.

Haataja, Kim (2009b): CLIL - Sprache als Vehikel oder "Einklang im Einklang"? Fremdsprache Deutsch, 40/2009, 5-12.

Helbig, Beate (2003): Bilinguales Lehren und Lernen. I: Bausch, Karl-Richard / Christ, Herbert / Krumm, Hans-Jürgen (Hrsg.) (2003): Handbuch Fremdsprachenunterricht. Tübingen: A.Francke (4. völlig überarbeitete Auflage), 179-186. 
Hellekjær, Glenn Ole (2007): Fremmedspråk i norsk næringsliv - engelsk er ikke nok! Fokus på språk 3. Halden: Fremmedspråksenteret.

Ibsen, Elisabeth (2004): Engelsk i Europa 2002. Acta Didacta 2/04.ILS. Oslo: Unipub.

Kästner, Harald (1993): Zweisprachige Bildungsgänge an Schulen in der Bundesrepublik Deutschland. Die Neueren Sprachen, 92, 23-53.

Kunnskapsdepartementet (2007): Språk åpner dører. Revidert utgave 2007. Oslo.

Kunnskapsdepartementet (2007): Språk bygger broer. St.meld. 23. Oslo.

Lamsfuß-Schenk (2008): Fremdverstehen im bilingualen Geschichtsunterricht: Eine Fallstudie. Frankfurt a.M.: Lang.

Lamsfuß-Schenk, S. / Wolff, Dieter (1999): Bilingualer Sachfachunterricht: Fünf kritische Anmerkungen zum state of the art”. Zeitschrift für Interkulturellen Fremdsprachenunterricht 4(2), http://zif.spz.tu-darmstadt.de/jg-04-2/beitrag/ lamsfus2.htm , 24.1.2012

Lindemann, Beate (2006a): CLILiG: Situationsbeschreibung in Norwegen. https://clillote-start.uta.fi/kooperation, 30.1.2012

Lindemann, Beate (2006b): CLILiG: Ergebnisse der Erhebung für Norwegen. https://clillote-start.uta.fi/kooperation, 30.1.2012

Lindemann, Beate (2009): Möglichkeiten und Grenzen für deutschsprachigen Fachunterricht. Fremdsprache Deutsch 40 (2009), 14-18.

Maier, W. (1991): Fremdsprachen in der Grundschule. Eine Einführung in ihre Didaktik und Methodik. Berlin/München: Langenscheidt.

Mordal, Siri / Lindemann, Beate / Aaslid, Bjørg Eva (2012): Evaluering av forsøk med 2. fremmedspråk på 6.-7.trinn. Delrapport 2. Oslo, Trondheim: Utdanningsdirektoratet, SINTEF.

Mordal, Siri / Lindemann, Beate / Aaslid, Bjørg Eva (2012): Evaluering av forsøk med 2. fremmedspråk på 6.-7.trinn. Sluttrapport. Oslo, Trondheim: Utdanningsdirektoratet, SINTEF

Neuner, Gerhard (2003): Bausch, Karl-Richard / Christ, Herbert / Krumm, Hans-Jürgen (Hrsg.) (2003): Handbuch Fremdsprachenunterricht. Tübingen: A.Francke (4. völlig überarbeitete Auflage), 399-402.

Ross, E. (1997) (Hrsg.): Berufsbezogenes Fremdsprachenlernen. Berlin

Rück, Heribert (2004): Fremdsprachen in der Schule. Französisch und Englisch. Landau: Knecht.

Rück, Heribert (2006): Fremdsprachenfrüherwerb: Geschichte, Gründe, Konzepte. I: Jung, Udo (Hrsg.) (2006): Praktische Handreichung für Fremdsprachenlehrer. 4., vollständig neu bearbeitete Auflage 2006, 392-401.

Sandfuchs, U. / Zumhasch, C. (1999): Bilinguales und bikulturelles Lernen: Planung, Konzept und Realität der deutsch-italienischer Grundschule in Wolfsburg. I: HermannBrennecke, G. (1999) (Hrsg.): Frühes schulisches Fremdsprachenlernen zwischen Empirie und Theorie. Münster, 41-54.

Speitz, Heike / Simonsen, Torill / Streitlien, Åse (2007): Evaluering av prosjektet "Forsøk med tidlig start av 2. fremmedspråk". Sluttrapport. Rapport 03/2007. TelemarksforskingNotodden. (også tilgjengelig som pdf-fil under: 
http://www.fremmedspraksenteret.no/nor/fremmedspraksenteret/fremmedsprak-pabarnetrinnet-1/tidligere-prosjekter/2005-_2007; 13.1.2012.

Thürmann, E. (2000): Zwischenbilanz zur Entwicklung der bilingualen Bildungsangebote in Deutschland. I: Helbig, Beate / Kleppin, Karin / Königs, Frank G. (2000) (Hrsg.): Sprachlehrforschung im Wandel. Beiträge zur Erforschung des Lehrens und Lernens von Fremdsprachen. Festschrift für Karl-Richard Bausch zum 60.Geburtstag. Tübingen: Narr, 473-497.

Wildhage, Manfred (2000): Bilingualer Unterricht in Niedersachsen. Neusprachliche Mitteilungen 53, 212-219.

Wode, Henning et al. (1996): Die Erprobung von deutsch-englisch bilingualem Unterricht in Schleswig-Holstein: Ein erster Zwischenbericht. Zeitschrift für Fremdsprachenforschung 7/1, 15-42.

Ytreberg, Lisbeth (1993): Engelsk i grunnskolen. Oslo: Tano.

Zydatiß, Werner (2000): Bilingualer Unterricht in der Grundschule. Entwurf eines Spracherwerbskonzepts für zweisprachige Immersionsprogramme. Ismaning: Hueber.

Zydatiß, Werner (2007): Deutsch-Englische Züge in Berlin (DEZIBEL). Eine Evaluation des bilingualen Sachfachunterichts an Gymnasien. Kontext, Kompetenzen, Konsequenzen. Frankfurt a.M.: Lang. 